\title{
А БЫЛ ЛИ ВЫБОР?
}

\author{
В.В. Уфимцев
}

УФИМЦЕВ Виктор Владимирович, доктор социологических наук, доцент, проректор Уральского института коммерции и права по научной работе, профессор кафедры политологии и социологии Института по переподготовке и повышению квалификации преподавателей социальных и гуманитарных наук при Уральском государственном университете имени А.М.Горького (г.Екатеринбург).

Хотелось бы принять участие в дискуссии о проблемах российского выбора, развернувшейся на страницах “Полиса” [Красин 2003; Пантин 2003; Кулинченко, Кулинченко 2003; Ильин 2003] и продолженной на III конгрессе политологов, участником которого автору этих строк посчастливилось быть. И сразу же задать вопрос, помещенный в заголовок статьи: а был ли у России выбор? То есть, соответствует ли нынешний вектор развития нашей страны изначальному добровольному выбору ее общества? Убежден: ответ должен быть отрицательным. Обратимся к недалекому прошлому.

К 1980-м годам в сознании советских людей реальный социализм стал качественно уступать порядкам, сложившимся в наиболее развитых западных странах. Последние демонстрировали свои преимущества не только в производстве и потреблении товаров, в политической демократии, но и в социальной защите населения. Видимо, это и заставило ряд историков сделать вывод о том, что “либерально-демократический выбор” России “носил добровольный характер и имел под собой объективную основу” [Согрин 1994: 5].

С точки зрения историка по образованию, такое заключение, очевидно, представляется справедливым. Но если проанализировать весь комплекс протекавших в стране общественно-политических процессов, то все окажется гораздо сложнее. Возможно, указанный выбор действительно носил добровольный характер, хотя многие социологические исследования свидетельствуют о другом: граждане СССР в большинстве своем желали тогда совершенствования социализма, мечтали о “социализме с человеческим лицом”. Однако вопрос заключается даже не в этом. Главное - кто и зачем этот скороспелый выбор навязывал? Да, либерально-демократическая модель предпочтительна, но как ее воплотить в жизнь на отечественной почве, какой ценой, с какими издержками и потерями? Вторую часть проблемы вольно или невольно скрыли от доверчивого населения, предполагая облегченный путь продвижения к данной модели.

Так или иначе, по мере развития процессов гласности и демократизации, под массированным давлением СМИ миллионы наших соотечественников превратились в “западников”, выказывая желание жить как в США или Швеции (правда, забывая, что нашу страну населяют отнюдь не американцы или шведы, да и вообще не задумываясь о том, соответствует ли такое желание реальным возможностям российского общества?). Западные (в первую очередь американские) социальные механизмы и институты стали между тем предметом почитания для многих и многих отечественных журналистов, новоиспеченных политиков, части интеллигенции, в т.ч. некоторых исследователей (Г.Попов, Л.Пияшева, Ю.Афанасьев, С.Станкевич, Ю.Черниченко, А.Мурашов и т.д.). Эти модели предлагались в качестве эталонов как телевидением и прессой, так и политическими движениями и партиями. И надо признать, рыночная идея овладела массовым сознанием. Общественность уже не воспринимала предостережения не только консерваторов (например, Е.Лигачева или Н.Андреевой, автора известной статьи “Не могу поступиться принципами”), но и диссидентов-эмигрантов, всю жизнь боровшихся с коммунистическим режимом (А.Солженицына, В.Максимова, А.Зиновьева и др.)

Здесь, по-видимому, уместно упомянуть статью А.Солженицына “Как нам обустроить Россию”, почти не замеченную изданиями, называвшими себя демократическими. Ее автор справедливо предупреждал о гибельности бездумного копирования зарубежного опыта, о том, что механическое заимствование чужеземных моделей неизбежно приведет к колониальному порабощению России [Солженицын 1990]. Не прислушались! 


\section{А БЫЛ лИ ВЫБОР}

Таким образом, можно заключить следующее: после 1991 г. “политическая элита” (как она себя сама называла) осуществила своего рода подлог. Народу “предоставили” не то, на что он рассчитывал. Вместо “социализма с человеческим лицом” вырос дикий капитализм XVII в. или современный капитализм заирско-колумбийского типа. Почему заирского? Потому что вовсю распродаются природные ресурсы. Почему колумбийского? Потому что в авангарде экономической, да и политической жизни на протяжении 1990-х годов стояла мафиозно-компрадорская плутократия, готовая на любой подрыв национальных интересов ради получения прибыли.

Возможность исправить данное положение открывалась в 1996 г. И электорат к этому был готов: к началу указанного года рейтинг президента Б.Н.Ельцина серьезно упал. И наоборот, рейтинг его основного соперника от блока народно-патриотических сил поднялся достаточно высоко, чтобы тот мог рассчитывать на победу. Но такому выбору не суждено было состояться. С помощью административного ресурса, теневых структур и скрытых финансовых потоков, когда оптом и в розницу было скуплено немало деятелей культуры, в условиях тотального контроля над СМИ удалось повысить популярность действовавшего главы государства и “купить” президентское кресло на второй срок (500 тыс. долл.

Лисовского-Евстафьева-Чубайса в коробке из-под ксерокса — это лишь маленькая толика “черного”, а следовательно, криминального “нала”, лишь верхушка айсберга). Посредством манипулятивных электоральных технологий и черных денежных потоков был осуществлен вторичный подлог.

То, что у власти в конечном итоге оказался нынешний президент России В.В.Путин, говорит не о демократических тенденциях массового сознания, а о начале реализации тенденций авторитарных, о становлении модели авторитарного выбора в нашей стране. Действительно, кого выбрали? Не демократа (например, Г.Явлинского). Голосовали, по существу, за председателя ФСБ, пусть и бывшего. То есть, после десяти лет демократических преобразований во главе государства встал руководитель “органов”. Возникает закономерный вопрос: почему после ряда лет хождения по кругу мы пришли к властной структуре, очень напоминающей предыдущую, дореформенную? И это — выбор России?

Ю.Красин и М.Ильин [Красин 2003; Ильин 2003] задаются вопросом: прошли ли мы точку бифуркации? В развитие дискуссии по данному вопросу мне хотелось бы предложить свою динамическую модель политико-социального равновесия, которая, на мой взгляд, применима к сегодняшней России (см. рис. 1). В этой модели я использую принцип равновесия и, соответственно, ввожу понятие точки равновесия (F).

Рассмотрим российское социальное пространство в предложенной системе координат. На вертикальной оси (C) обозначим степень государственного и общественного воздействия (санкций) на социальное пространство; на горизонтальной $(\mathrm{L})$ - уровень либерализации. Нисходящая кривая DD - спрос совокупности индивидов в обществе на свободу действий. Этот спрос находится в обратной зависимости от возможных санкций.

Восходящая кривая RR - ресурсное обеспечение социальной либерализации. Она отражает взгляд на социальное пространство “глазами” аппарата государственного управления. Чем выше спрос общества на либерализацию, тем больше ресурсов на первоначальном этапе необходимо задействовать, чтобы обеспечить требуемый уровень либерализации. Здесь уже прослеживается прямая зависимость.

Идеальным состояниям общества является нахождение в точке равновесия $\mathrm{F}$, соответствующей $\mathrm{C} 0-$ оптимальной степени государственного и общественного воздействия на социальное пространство. Именно в точке F реально гражданское общество, когда найден баланс между возможностями государства (“учреждения”, по И.А.Ильину), с одной стороны, и общественного самоуправления (“корпорации”) — с другой.

Любая социальная система стремится к равновесию, поэтому предполагалось, что от диктатуры, от авторитарно-тоталитарного режима наша страна перейдет к демократии, достигнет точки равновесия $\mathrm{F}$ при снижении государственного воздействия с С1 (уровень диктатуры) до С0. Но этого не произошло по ряду причин $[1]$.

В каком же месте оказалось российское общество в настоящий момент? Очевидно, что мы находимся на уровне C2, т.е. намного ниже точки равновесия F. Это означает, что наше общество переживает социальную аномию, оно анархично, расплывчато, структурно незафиксированно. Такое положение позволяет говорить о бифуркационном застое (или бифуркационном дрейфе) сегодняшней России. 
При С2 - слишком низком уровне воздействия - спрос на свободу действий со стороны населения, социальных слоев и групп находится в точке K и соответствует L2, возможной степени социальной либерализации; уровень же ресурсного обеспечения находится в точке I. То есть отрезок IK - это уровень аномии в обществе. Но, повторю, социальная система стремится к равновесию. И такого равновесия или квазиравновесия (в зависимости от того, какие средства будут использованы для его достижения) в принципе можно достичь. В условиях социальной аномии население скоро почувствует, что “так жить нельзя”. Следствия анархии, низкой управляемости общества в той или иной степени задевают всех граждан, и они начинают требовать от государства повысить степень властного воздействия на систему - с уровня С2 до уровня С0.

Если же, несмотря на давление общества, уровень санкций со стороны государства не повышается указанным образом (из-за нехватки ресурсов, скудного финансирования или по каким-то другим причинам), то возникший дефицит власти замещается другими институтами и другими методами. При этом объект управления (население, его слои) может прибегать как к социально ориентированным (со знаком “плюс”), так и к асоциальным (со знаком “минус”) способам действия. К числу вторых относятся: обращение к организованным преступным группам за защитой или для “решения” отдельных вопросов; уход предпринимателей под так наз. бандитские “крыши”; выплата (добровольная и недобровольная) мафиозного налога в обмен на “порядок” на определенной территории; обращение к тоталитарным сектам и т.д. Разнообразен и спектр способов “со знаком плюс”. Здесь, прежде всего, стоит упомянуть непосредственное финансирование государственных структур объединениями граждан и/или различными частными организациями (наем милиционеров для охраны школ и других объектов, организация патрулирования на городских улицах за счет местных сообществ и т.д.).

В случае увеличения масштабов социальной анархии государство может поднять уровень санкций с С2 до С0 с помощью ресурсных (финансовых) вливаний, что позволит ему заместить собой криминальные структуры и привести систему в равновесие. То есть, задача решается путем усиления авторитарной составляющей. Но это неизбежно связано с ростом коррупции. Другой путь — коренное улучшение качества субъекта управления. Речь идет о повышении эффективности управленческих структур (и их аппарата) посредством административной и других реформ. Указанные структуры, повысив за счет продуманных инвестиций в систему управления свой потенциал, вполне могут обеспечить более высокий уровень социальной либерализации, соответствующий точке K (L2 вместо L1) при тех же текущих затратах (C2) (cм. пунктирную кривую R2 на рис. 1). Третий путь - создание условий для роста политической и общей культуры самого населения, его гражданское просвещение, т.е. повышение качества объекта управления (см. пунктирную кривую D2, обеспечивающую равновесие в точке I при санкциях C2.). 


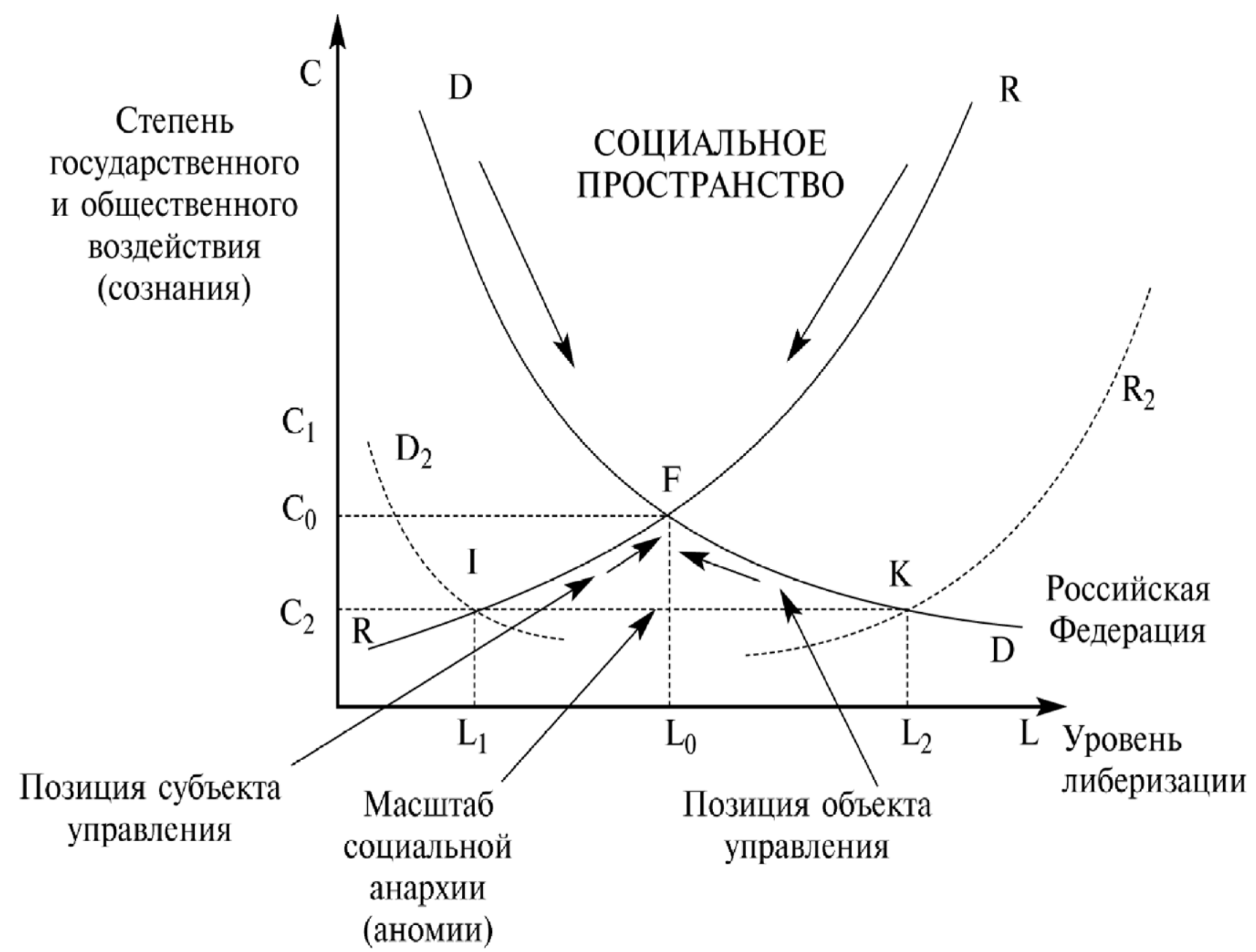

Рисунок. 1. Динамическая модель политико-социального равновесия в обществе

Таким образом, мы выявили основные пути приведения социальной системы в равновесие. Более того, применив метод равновесного анализа к социальным процессам и явлениям, мы получили абстрактно-логическую схему системы политико-социального равновесия, позволяющую моделировать механизмы достижения и поддержания подобного равновесия в постсоветском обществе. Точка равновесия $\mathrm{F}$, которая может смещаться в зависимости от смещения кривых, и будет соответствовать подлинному, а не мнимому выбору России. Именно здесь находится истинный баланс между возможностями институтов формирующегося “снизу” гражданского общества и властными полномочиями государства. Задача государства, указанных институтов, политического класса — помочь обществу достичь этой точки равновесия и тем самым приблизиться к гармонии объективного выбора.

Ильин М.В. 2003. Российский выбор: сделан, отсрочен, отменен? - Полис, № 2.

Красин Ю.А. 2003. Политическое самоопределение России: проблемы выбора. - Полис, № 1.

Кулинченко В.А., Кулинченко А.В. 2003. О духовно-культурных основаниях модернизации России. Полис, № 2.

Пантин И.К. 2003. Демократия в России: противоречия и проблемы. — Полис, № 1.

Согрин В.В. 1994. Политическая история современной России. 1985 - 1994: от Горбачева до Ельцина. М.

Солженицын А.И. 1990. Как нам обустроить Россию. - Комсомольская правда, 18.09. 
[1]Кривые способны сдвигаться вследствие воздействия на них внесистемных факторов, в результате чего точка F может быть блуждающей. Рассмотреть это смещение не позволяет объем журнальной статьи. 